\title{
Farming the floodplain: \\ New England river governance in a changing climate
}

Rachel E. Schattman, Ph.D.

November 9, 2017

USDA United States Department of Agriculture 


\section{Background}

- River governance is notoriously complex.

- Climate change will alter how people interact with rivers.

- Will current river governance structures serve us in the future? Or is it time to reconsider our current rules and regulations?

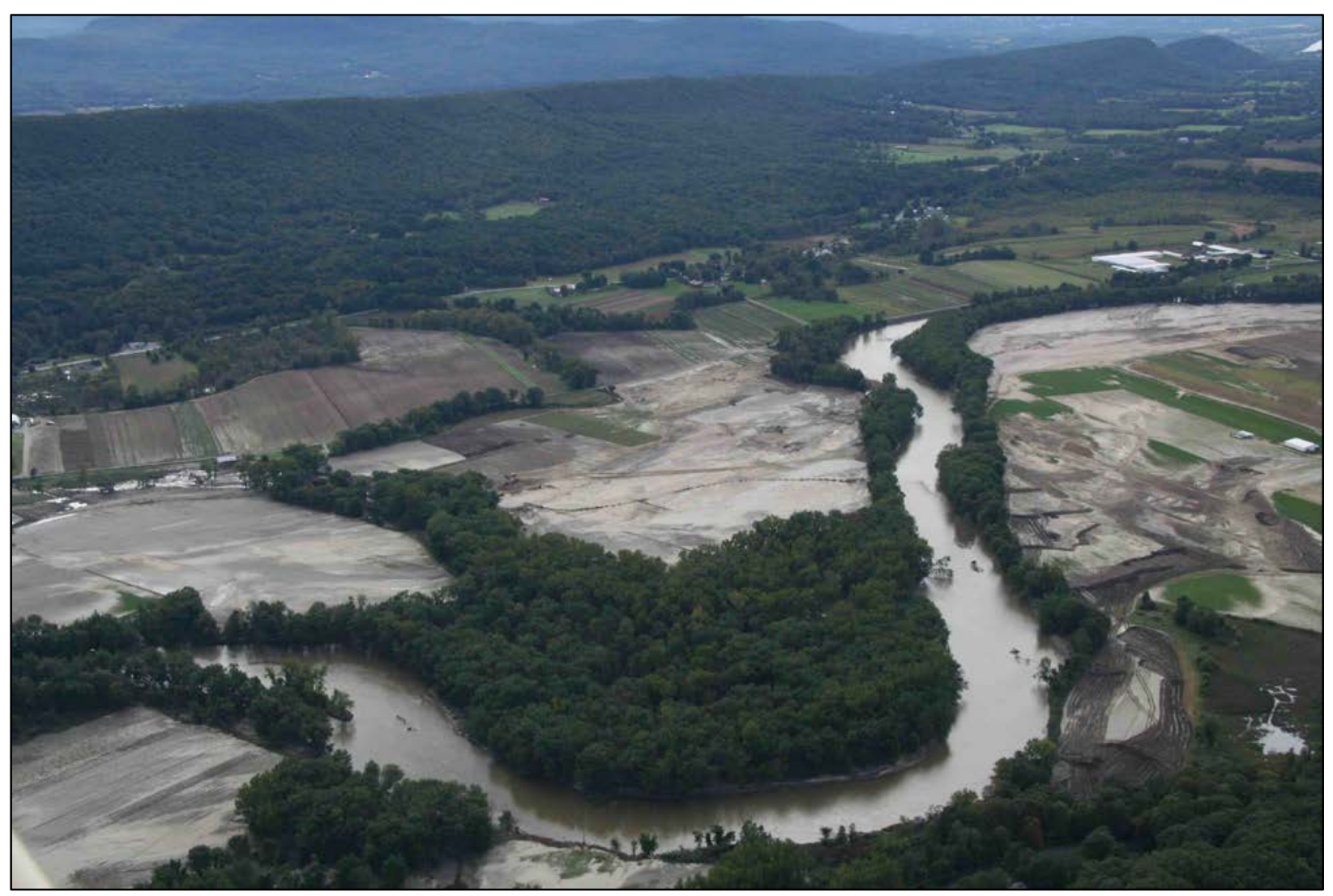




\section{Objectives}

1. Introduce theoretical frames: Vulnerability, adaptation, river governance

2. Review case study: New England river governance in a changing climate

3. In class role-playing activity

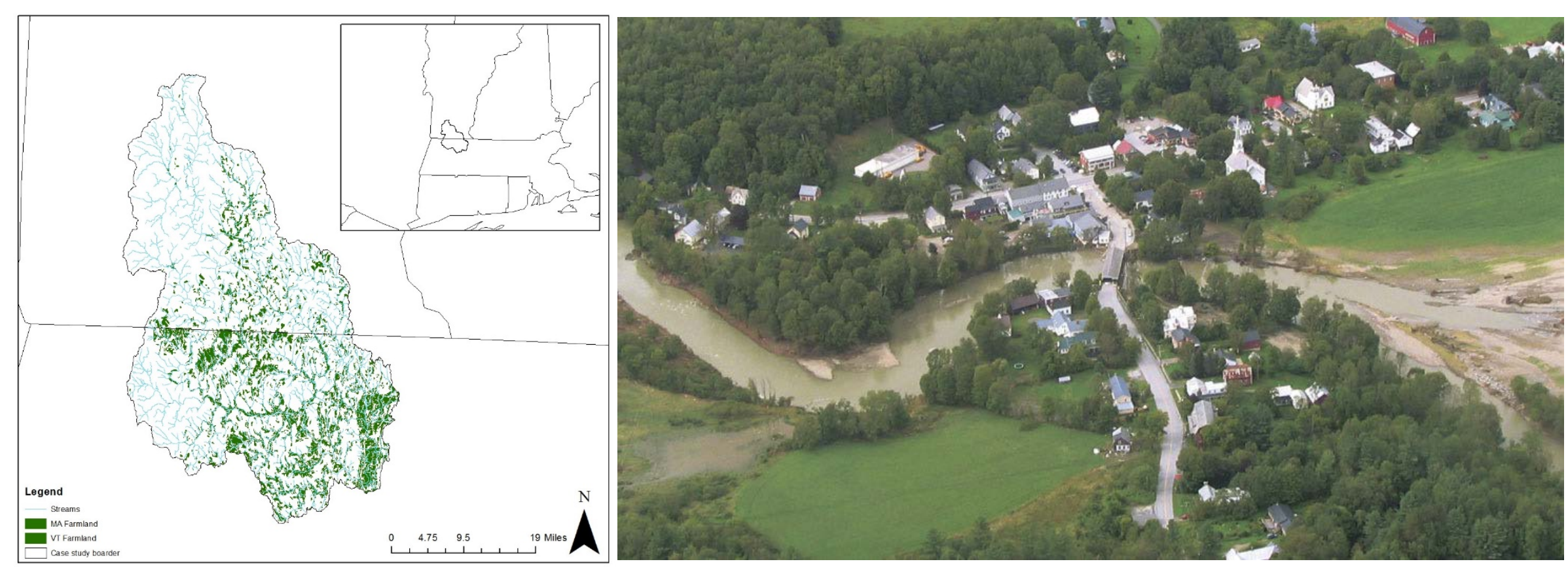

Map of case study area 


\section{Theoretical Frame}

Vulnerability $=[$ Exposure $*$ Sensitivity $]$ - Adaptive Capacity

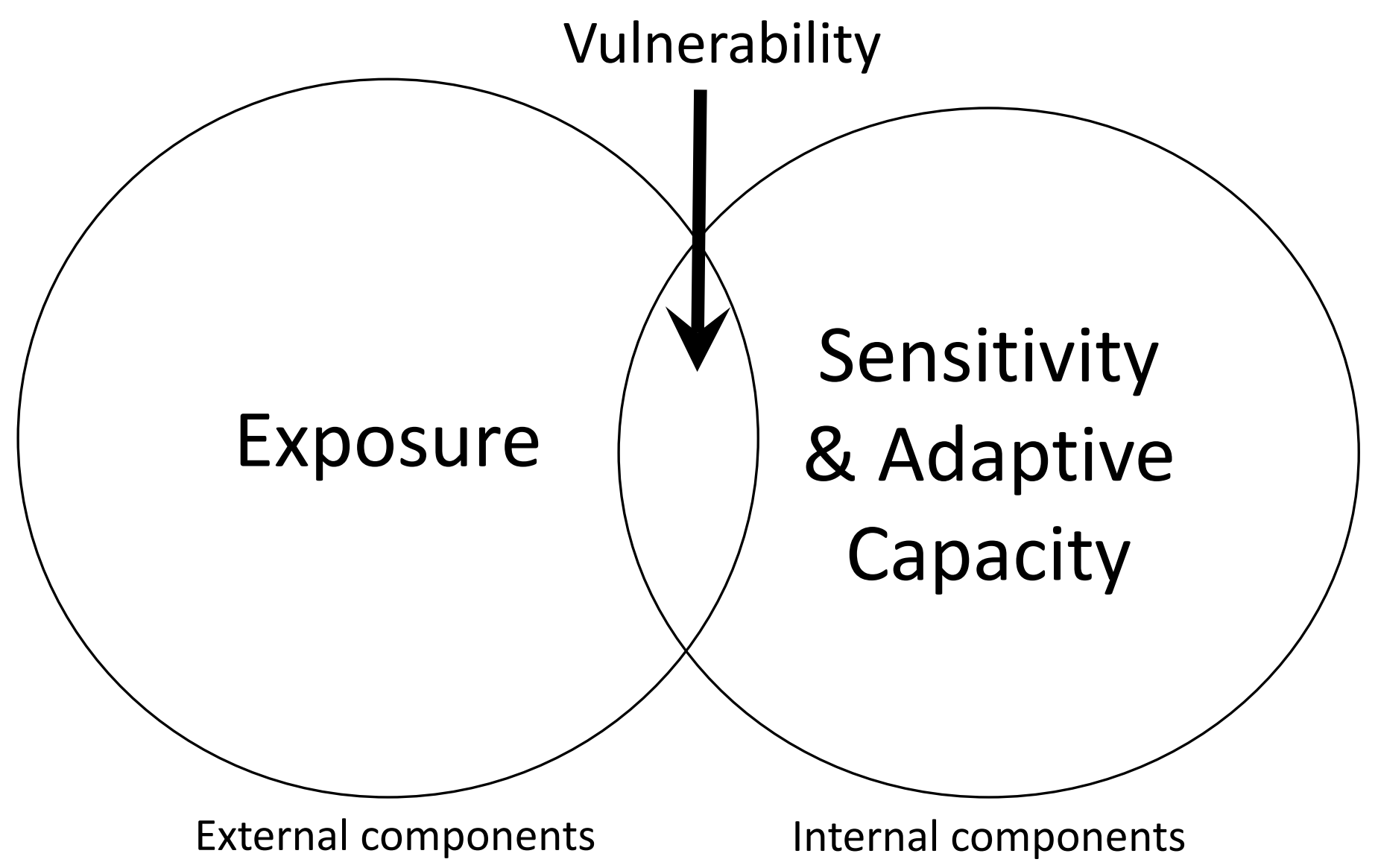




\section{Theoretical Frame}

Tools to reduce vulnerability in agroecological food systems

\section{Buffer}

Low cost.

Maintain operations, form and function of the business. 


\section{Theoretical Frame}

\section{Tools to reduce vulnerability in agroecological food systems}

\section{Buffer}

Low cost.

Maintain operations, form and function of the business.

\section{Adapt}

Medium cost.

Shift operations, but maintain form and function of the business. 


\section{Theoretical Frame}

Tools to reduce vulnerability in agroecological food systems

Buffer

Low cost.

Maintain operations, form and function of the business.

\section{Adapt}

Medium cost.

Shift operations, but maintain form and function of the business.

\section{Transform}

High cost.

Dramatically alter the form and function of the business. 
Scenario 1: Increasing ocean acidity over several decades negatively impacts lobster populations

\section{Buffer}

Low cost.

Maintain operations, form and function of the business.

\section{Adapt}

Medium cost.

Shift operations, but maintain form and function of the business.

\section{Transform}

High cost.

Dramatically alter the form and function of the business. 


\section{Theoretical Frame}

\section{Scenario 2: Increasingly long and severe seasonal droughts}

\section{Buffer}

Low cost.

Maintain operations, form and function of the business.

\section{Adapt}

Medium cost.

Shift operations, but maintain form and function of the business.
Transform

High cost.

Dramatically alter the form and function of the business. 


\section{Social dimension}

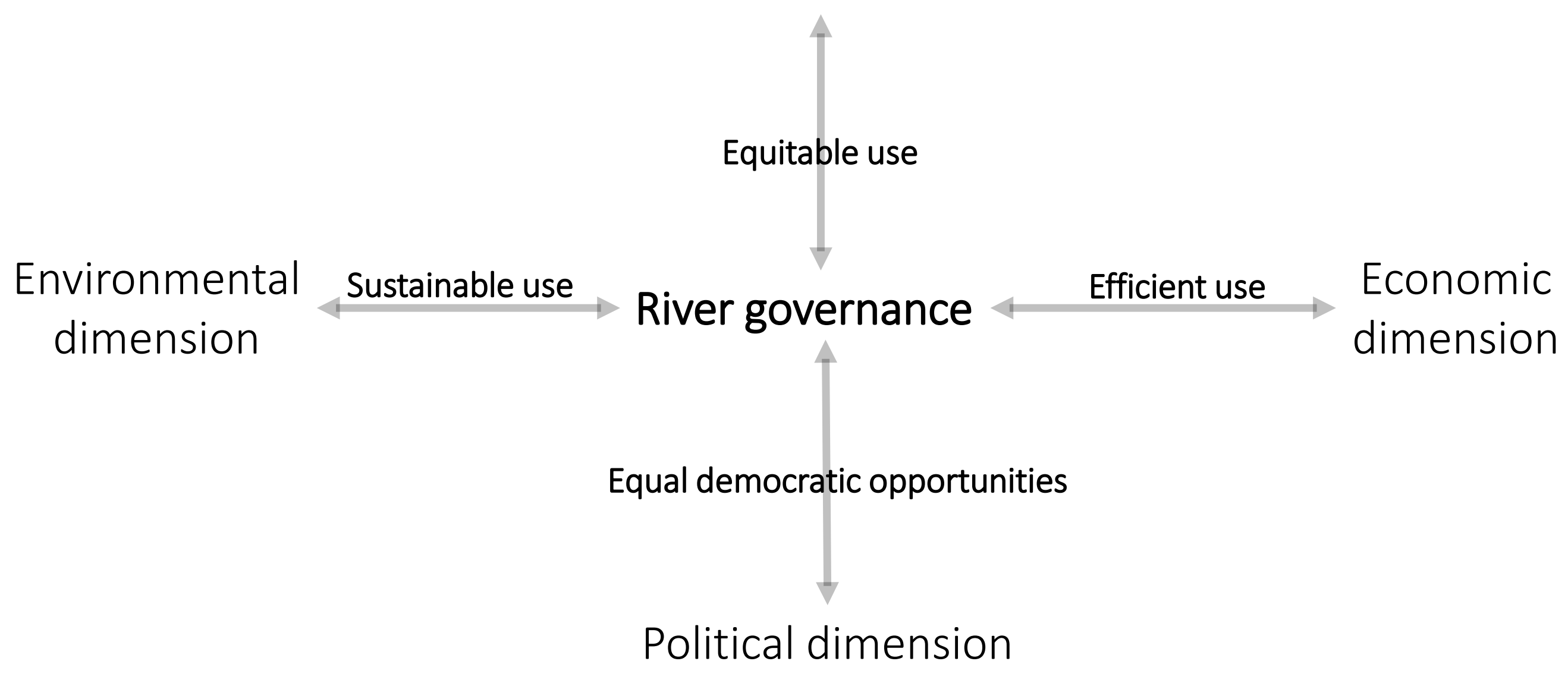




\section{Case study}

Farming in the floodplain

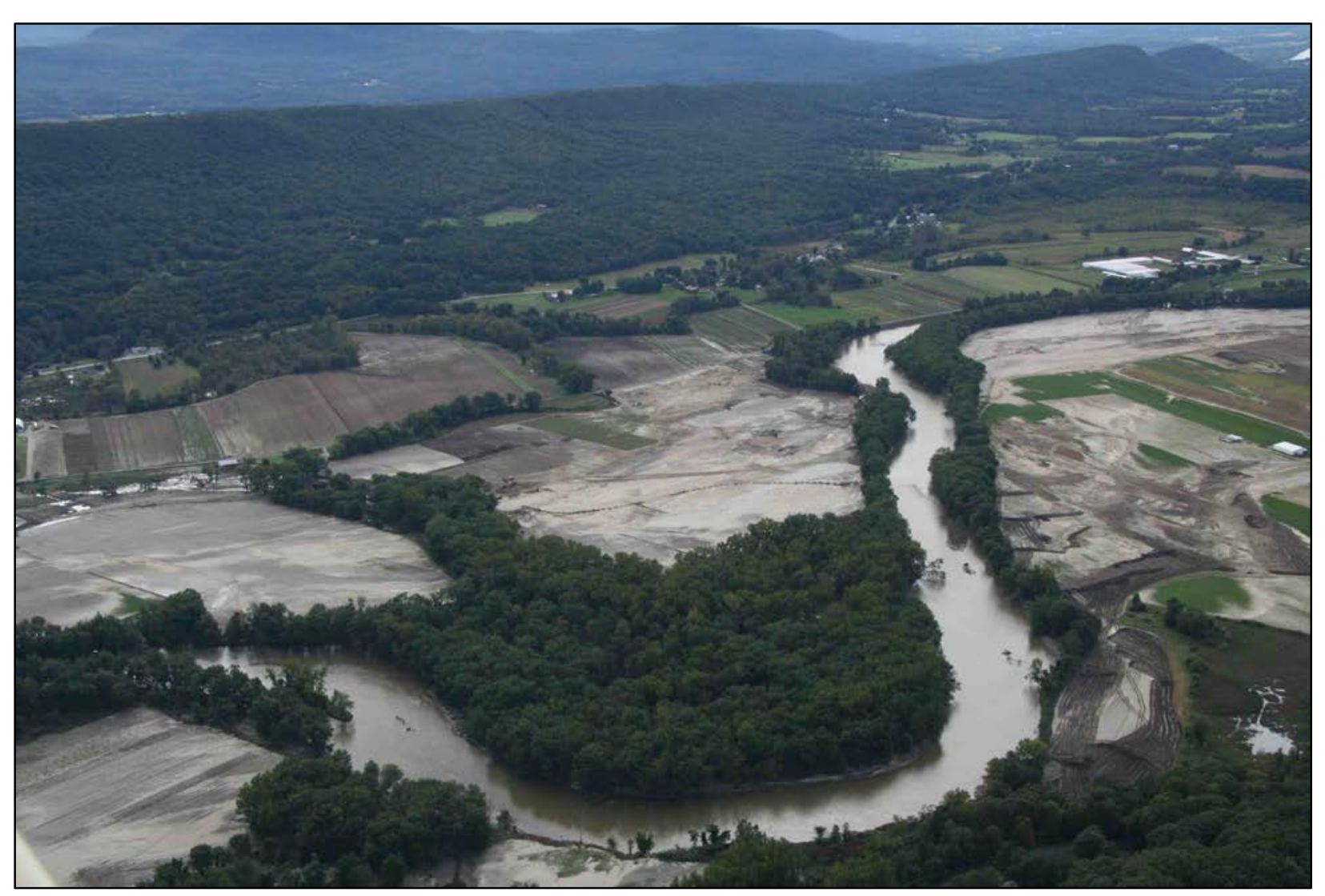




\section{Case study}

Increasing flood frequency reported in New England between 1940 - 2013

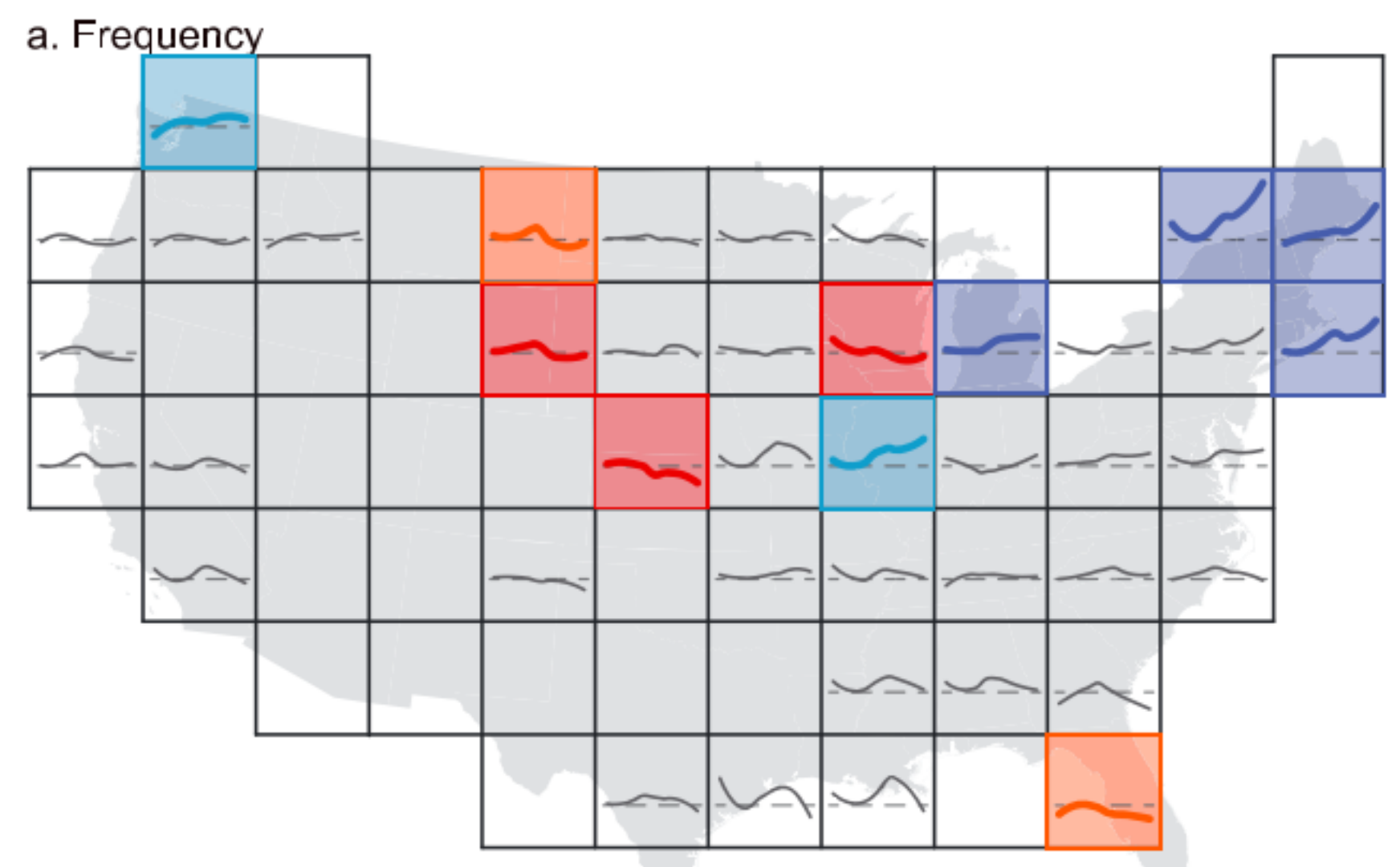




\section{Case study}
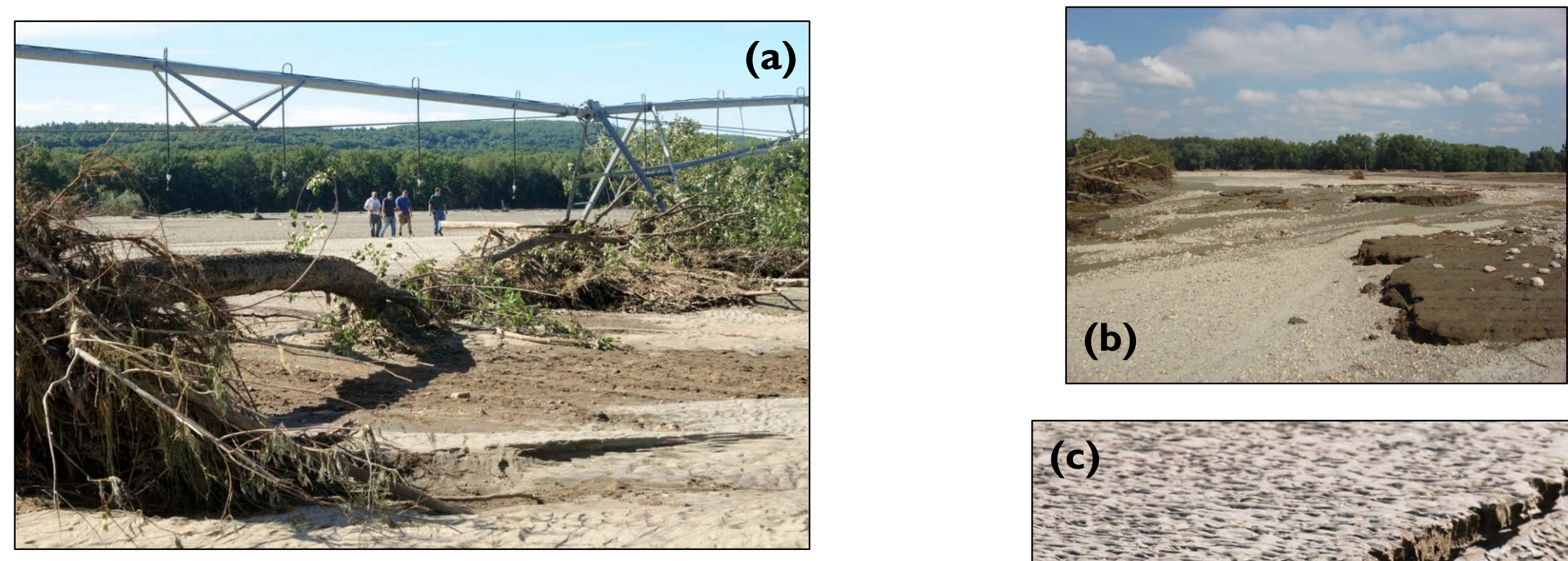

Flood damage to farm in Western MA after flood event in August, 2011.

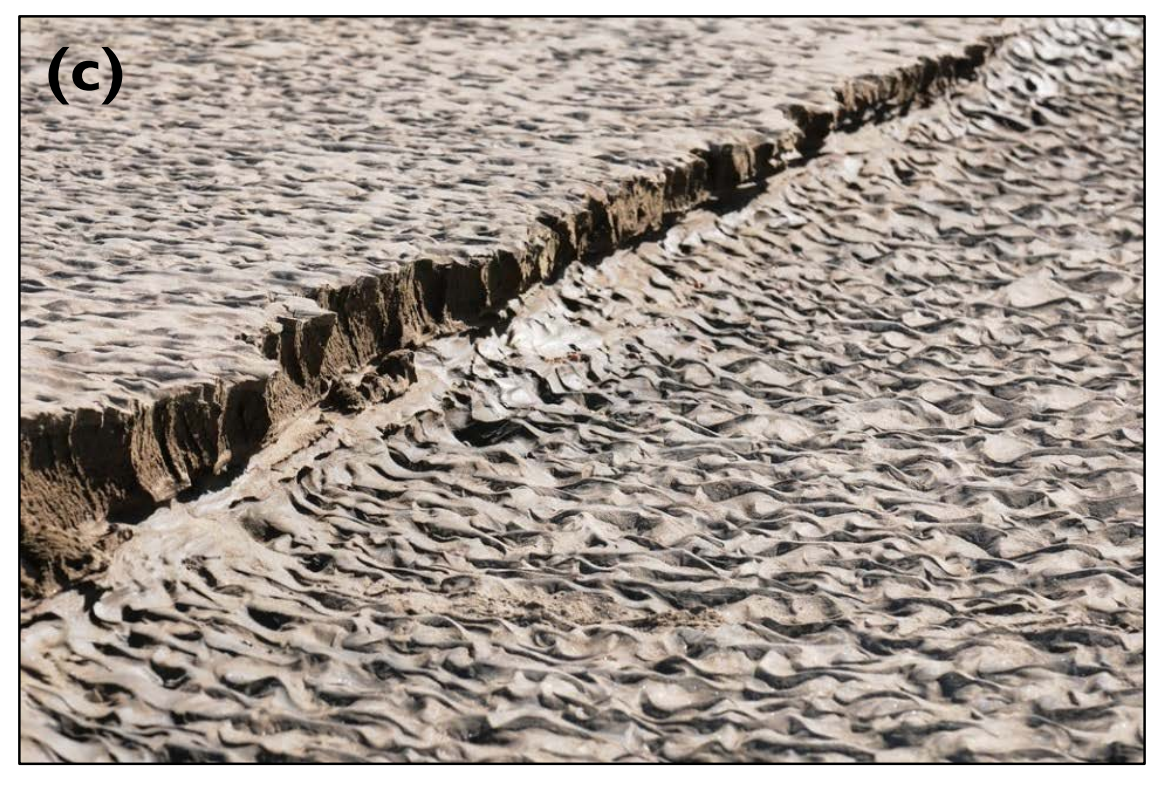




\section{Case study}

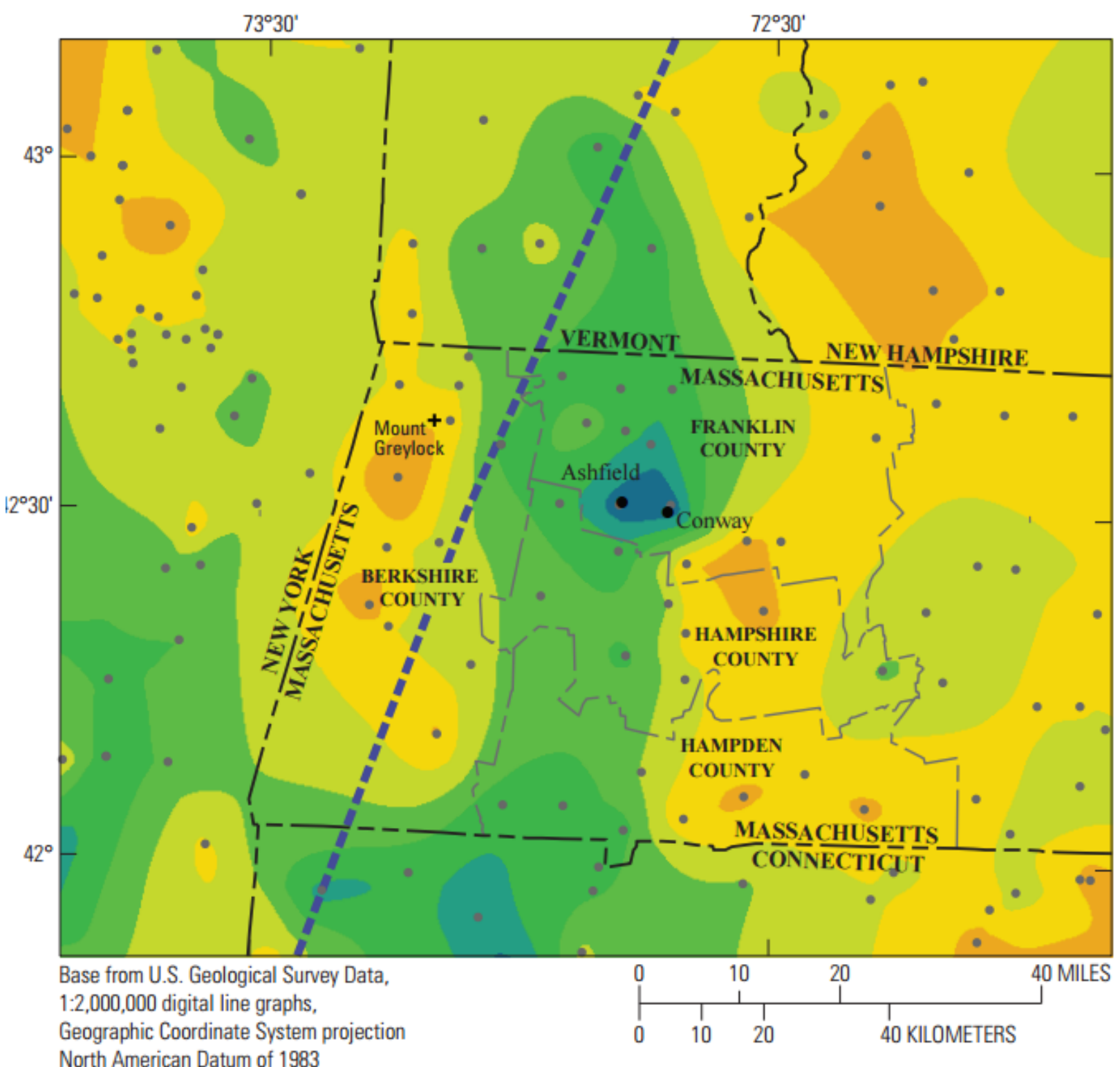

\section{EXPLANATION}

Total storm rainfall, in inches

3.01 to 4

4.01 to 5

5.01 to 6

6.01 to 7

7.01 to 8

8.01 to 9

9.01 to 10

- = Path of tropical storm Irene

- Rainfall data collection points

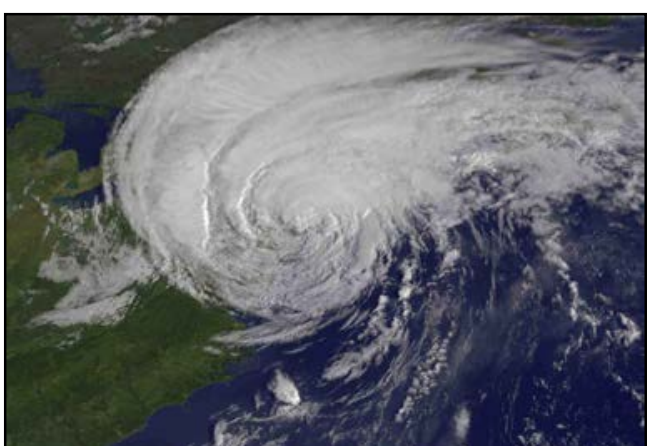

NASA 2011: Hurricanes/Tropical

Cyclones

Hurricane Season 2011: Hurricane

Irene 


\section{Case study}

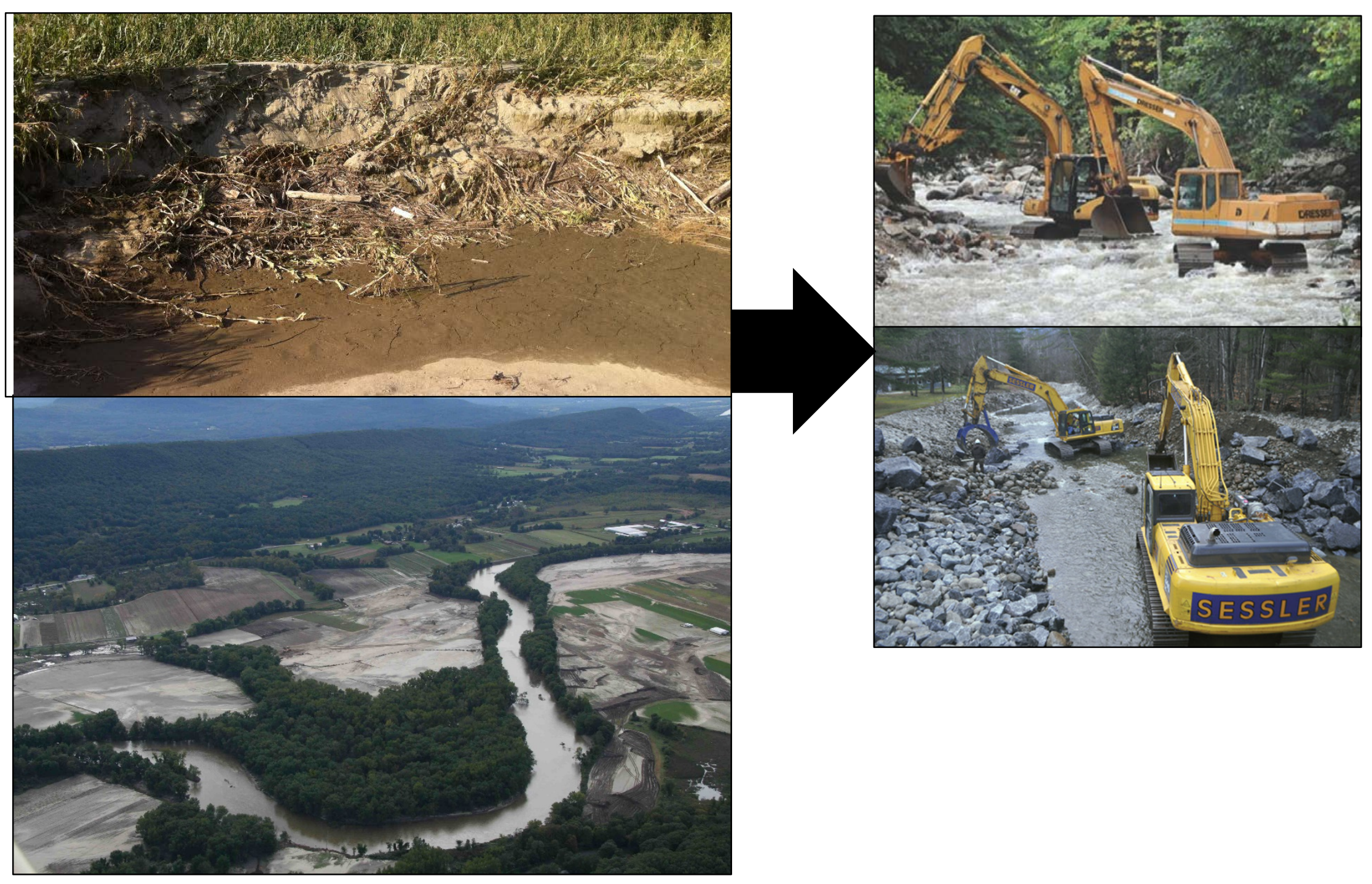

Farms in Western MA, Sept. 2011, post Tropical Storm Irene 


\section{Case study}

New England agriculture is vulnerable to flooding

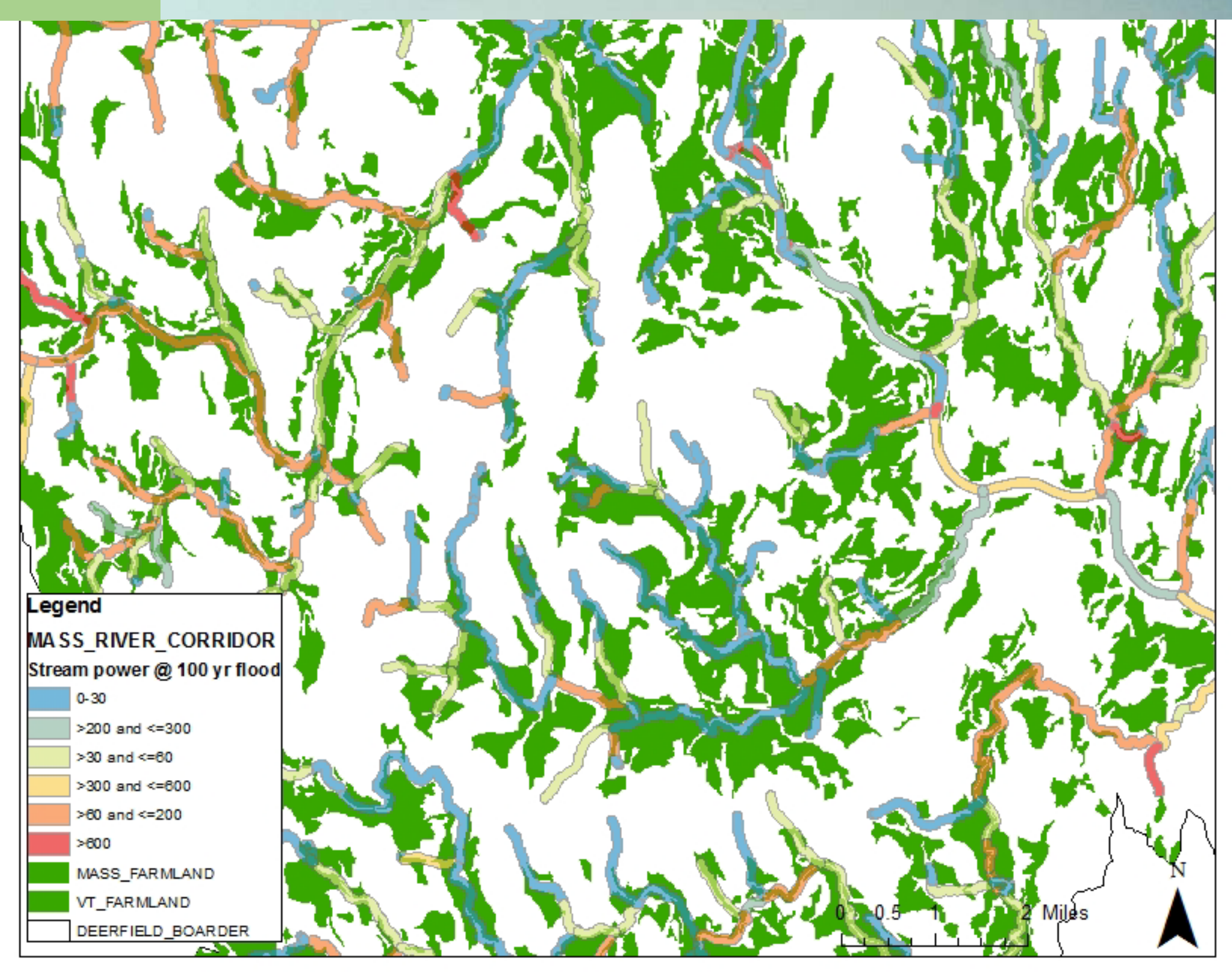




\section{Case study}

In Massachusetts, management of river corridors and vegetative buffers is highly regulated 


\section{Case study}

Flood impacts to farms and some farmers' perceptions of them

\begin{tabular}{|l|l|l|l|}
\hline $\begin{array}{l}\text { Exposure } \\
\text { type }\end{array}$ & Vulnerability & $\begin{array}{l}\text { Degree of } \\
\text { sensitivity }\end{array}$ & Farmer descriptions \\
\hline Inundation & $\begin{array}{l}\text { Equipment } \\
\text { loss }\end{array}$ & High & $\begin{array}{l}\text { “I lost some equipment. It flooded an out } \\
\text { building of mine that was closer to the river } \\
\text { and some equipment and materials that I had } \\
\text { in there were just swept downstream. They're } \\
\text { probably somewhere in the Atlantic by now." }\end{array}$ \\
\hline Inundation & Crop loss & High & $\begin{array}{l}\text { "We had about five or six acres that was just } \\
\text { flattened and destroyed; the impact of the } \\
\text { Irene was total loss of 40 acres of corn." }\end{array}$ \\
\hline Inundation & Soil moisture & Medium & $\begin{array}{l}\text { "The big issue was the land drying out, so I } \\
\text { could get to it." }\end{array}$ \\
\hline Erosion & Tree damage & Low & $\begin{array}{l}\text { "We probably lost 50-75 big pine trees. They } \\
\text { got pushed right over in sort of a line. I was } \\
\text { afraid I was going to be my whole sugar bush, } \\
\text { and l'd be out of maple sugaring!"” }\end{array}$ \\
\hline Erosion & $\begin{array}{l}\text { Soil erosion } \\
\text { (riverbank) }\end{array}$ & High & $\begin{array}{l}\text { "Oh Christ, I probably lost 2-4 acres in that ... } \\
\text { [Hurricane] Irene, probably 2-4 acres, it's } \\
\text { gone." }\end{array}$ \\
\hline
\end{tabular}




\section{Case study}

\section{Flood impacts} to farms and some farmers' perceptions of them

\begin{tabular}{|l|l|l|l|}
\hline $\begin{array}{l}\text { Adaptation } \\
\text { practice }\end{array}$ & Reason & Tradeoffs & Farmer descriptions \\
\hline $\begin{array}{l}\text { Bank } \\
\text { stabilization/ } \\
\text { dredging }\end{array}$ & $\begin{array}{l}\text { Protect crop and } \\
\text { pasture lands from } \\
\text { erosion; protect } \\
\text { critical } \\
\text { infrastructure }\end{array}$ & $\begin{array}{l}\text { Increases } \\
\text { downstream } \\
\text { flood impacts; } \\
\text { degrades river } \\
\text { ecosystems }\end{array}$ & $\begin{array}{l}\text { “I hired a fellow with a mini excavator } \\
\text { and brought in stone and they built up } \\
\text { the bank...it probably cost ten } \\
\text { thousand dollars or more." }\end{array}$ \\
\hline $\begin{array}{l}\text { Land use change } \\
\text { protect } \\
\text { croplands by } \\
\text { preventing soil } \\
\text { erosion }\end{array}$ & $\begin{array}{l}\text { Reduces } \\
\text { diversity of } \\
\text { local } \\
\text { agriculture }\end{array}$ & $\begin{array}{l}\text { "By '85 it was hay. Since then it's been } \\
\text { hay.We plowed it that one time and } \\
\text { we've never plowed it again, just for } \\
\text { that risk [of flooding], because in the } \\
\text { spring, the roots aren't deep enough if } \\
\text { it floods in the spring. I don't need a } \\
\text { I2-foot ditch in the center of the } \\
\text { field.” }\end{array}$ \\
\hline $\begin{array}{l}\text { Levee/block } \\
\text { flood water }\end{array}$ & $\begin{array}{l}\text { Protect } \\
\text { crops/fields from } \\
\text { multiple flood } \\
\text { impacts }\end{array}$ & $\begin{array}{l}\text { Increase } \\
\text { downstream } \\
\text { flood impacts } \\
\text { huge stones on the embankment up } \\
\text { there ... Gosh, they've got to be 20 to } \\
\text { 30 feet from the water. It's forming } \\
\text { that barrier [between the river and } \\
\text { the field]." }\end{array}$ \\
\hline
\end{tabular}




\section{Case study}

Other stakeholder perspectives on farmer adaptation to flooding:
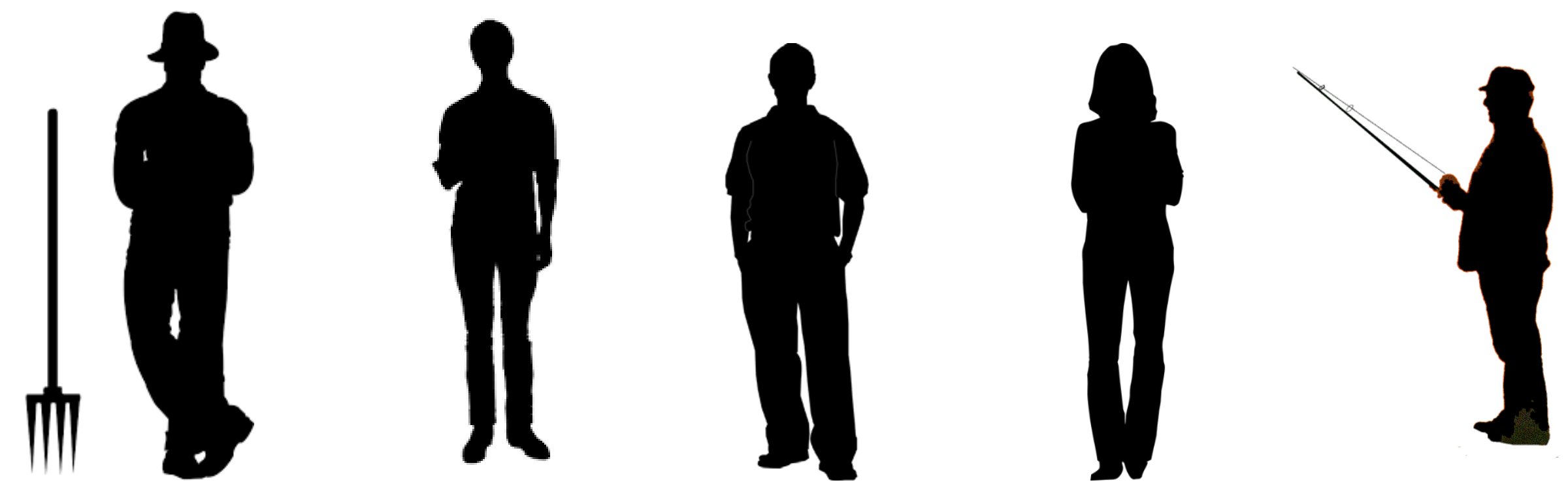

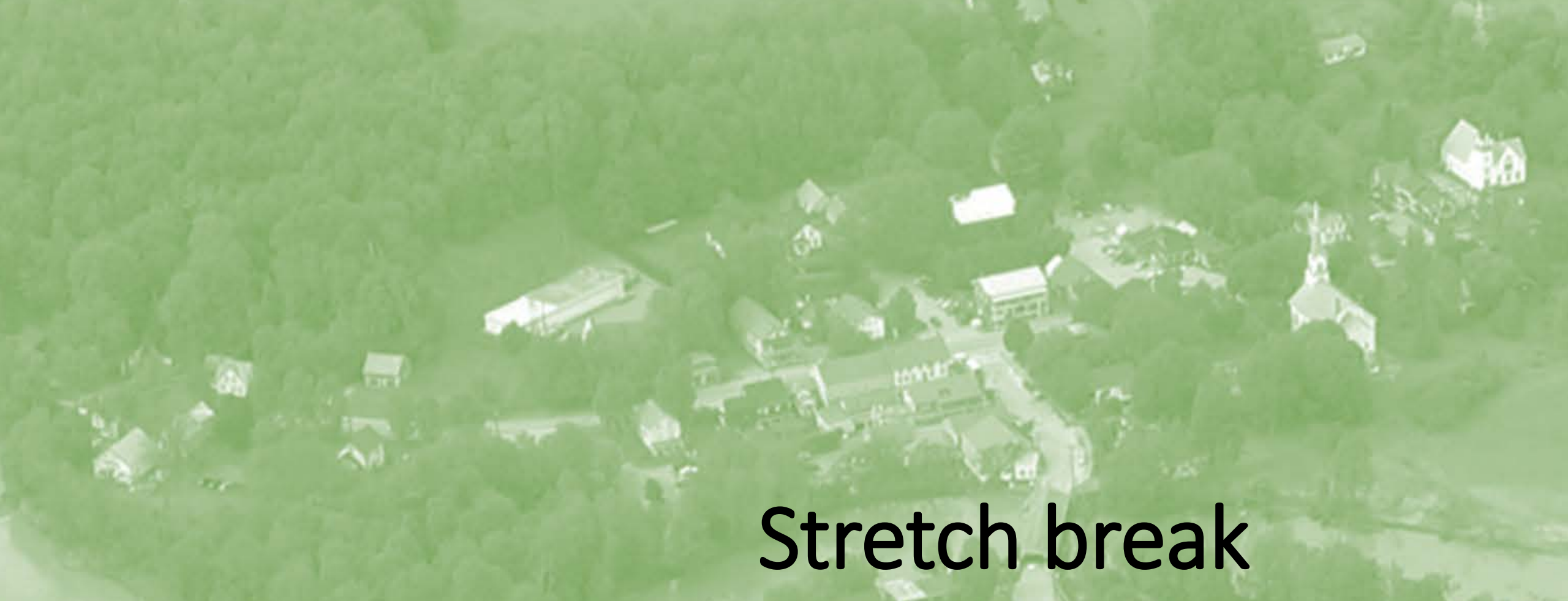

\section{Stretch break}
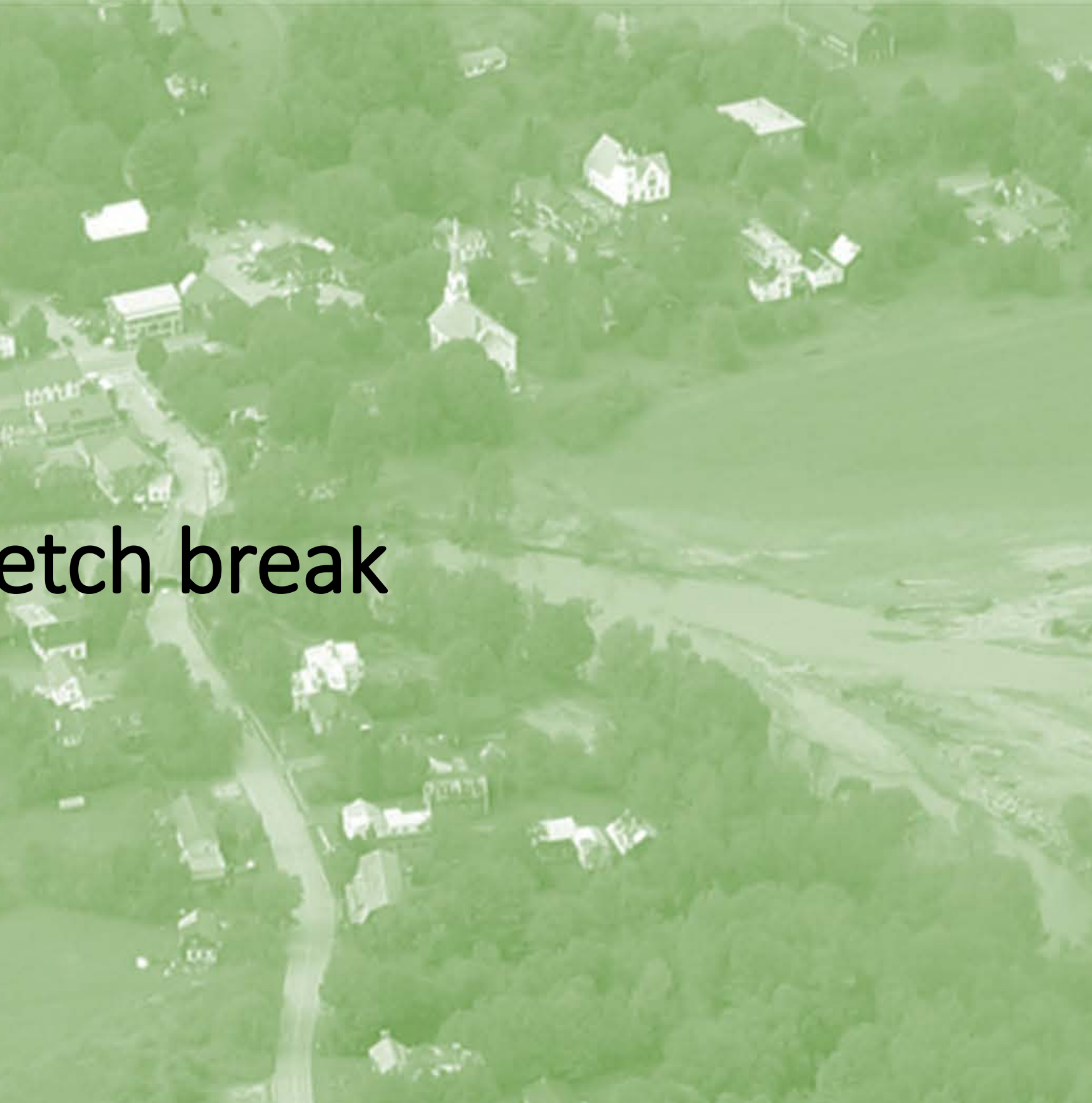


\section{Role play activity}

1. Divide into groups based on assigned role; develop a list of what your group wants from a new river governance structure. What may you be willing to compromise on? What are your key priorities for negotiation? (10 minutes)

2. Come back together as a class to develop the best possible river management plan using the river governance framework. (20 minutes)

3. By the end of the activity, all five stakeholders have been heard and have agreed in a common strategy.
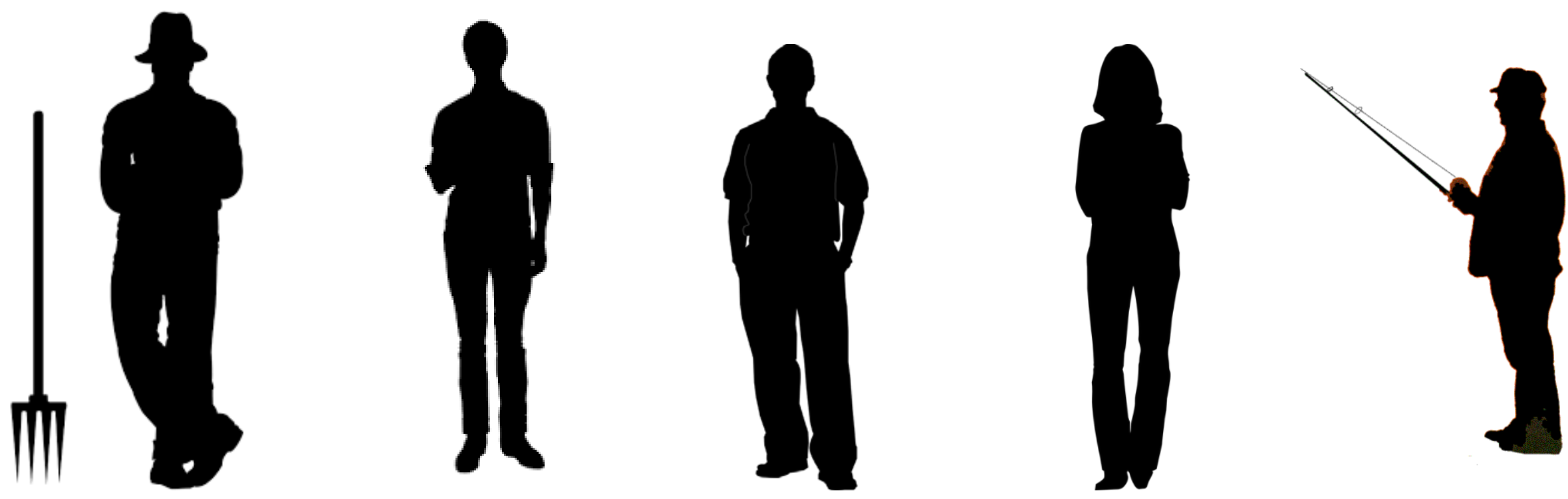


\section{Role play activity}

\section{RIVER MANAGER}

You are a Massachusetts river manager, and your goal is to promote mixed-use management of rivers. You are to ensure that any new management scheme is both environmentally and socially conscious. Your responsibility in your group is to facilitate and to ensure that all members of the group are able to share their ideas and contribute to the development of a new plan. Ultimately, you must ensure that any proposed plan includes all elements of the sustainable governance framework provided in the case study. 


\section{Role play activity}

\section{FARMER}

You farm 40 acres of vegetable fields in northwest Massachusetts. Your family has farmed this land for six generations. Very recently, you have experienced major losses of farmland and topsoil due to flooding of the river that runs through your property. In the past you have used your tractor to dredge the river and have placed large stones along its banks to reduce erosion. While this protects your field, it also increases the velocity of the water. This is a problem because you are directly upstream of a small town. You must work with residents, fishers, and other stakeholders to develop a management plan that may meet your needs and the needs of the other stakeholders. 


\section{Role play activity}

\section{FISHER/RECREATIONALIST}

You have fly-fished trout in Western Massachusetts and Southern Vermont for most of your adult life. You consider it more than a hobby as you describe it as a lifestyle. Recently, you have noticed that the number fish in local rivers are decreasing because trout habitat-which is essentially wild, unaltered stretches of river-is being reduced. This reduction is being caused as people who live and work along the river try to protect themselves from floods by building levees, shoring up riverbanks with rocks, or dredging the rivers to make more space for water. You side with the Environmentalist in that the solution would be to move all people and human activities away from rivers. But, you must work with those people in your group to develop a plan to meet all your river management needs. 


\section{Role play activity}

\section{RESIDENT}

You are worried about flood impacts from the river that borders your property. While you have considered building a levee and placing stones along the bank to protect you land and house from erosion, you do not have the equipment or expertise to do so. Additionally, you have seen water velocity in the river increase because the farmer upstream has channeled the river. You blame the farmer for putting your land and house at greater flood risk. You think that upstream land should be allowed to flood to slow water velocity and absorb floodwaters; this would protect you and your neighbors from future floods. 


\section{Role play activity}

\section{ENVIRONMENTALIST}

You have dedicated your life to protecting wild places across New England. You have recently joined with fishers in advocating for the protection of rivers in Western Massachusetts and Vermont. You advocate for a buy-out program in which the states allocate money to purchase all land along certain rivers to remove people and human activities. You see any manipulation of the river as uncalled for. 


\section{Role play activity}

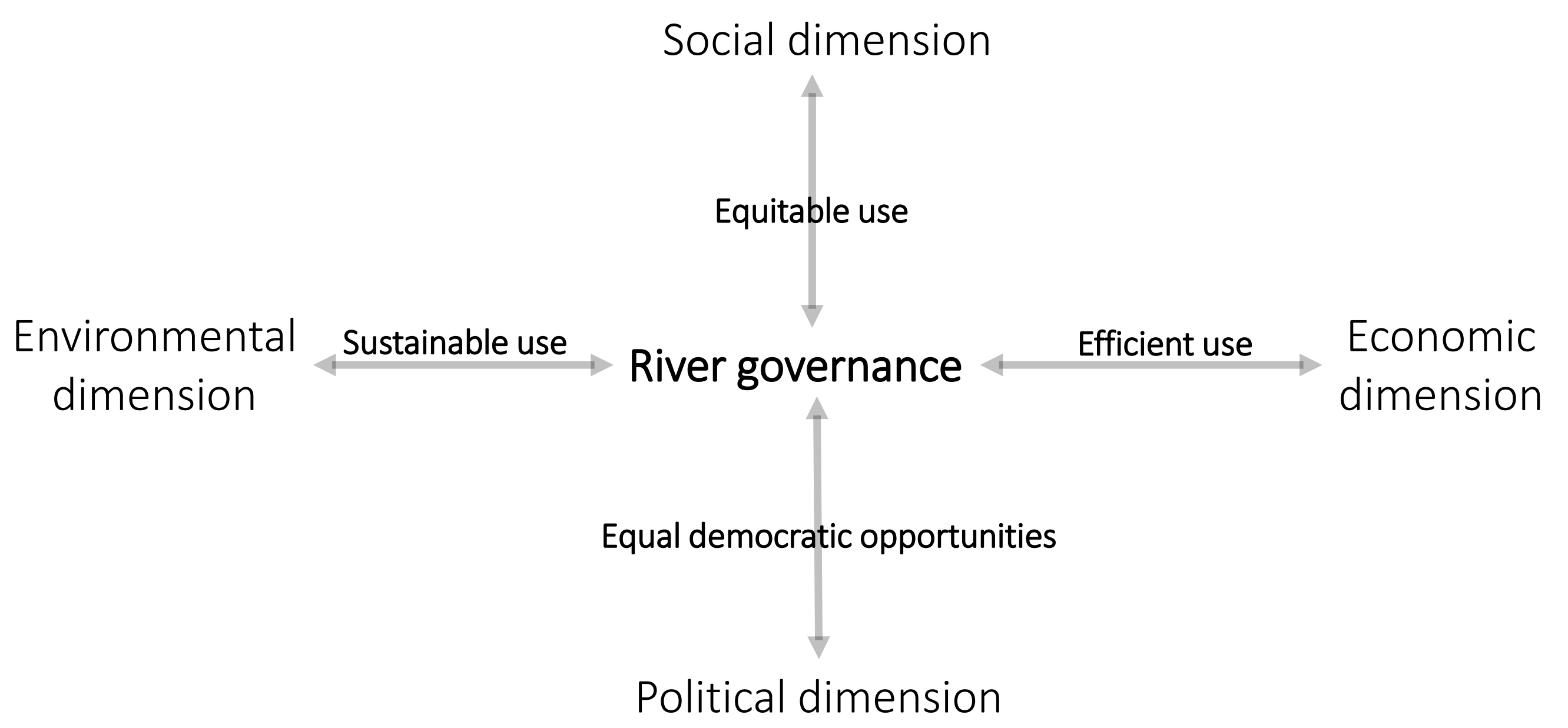




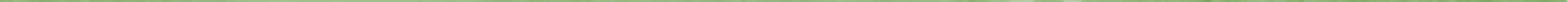

